UDC 544.653.2:547.571

COBISS.SR-ID 253159180

Original research paper

Acta Agriculturae Serbica, Vol. XXII, 44 (2017); 169-183

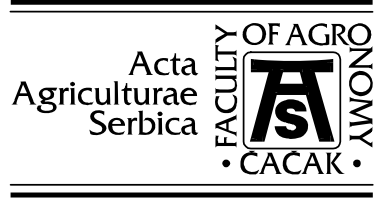

\title{
Effect of current density and solution composition on current efficiency for the electrochemical reduction of benzaldehyde
}

\section{Lenka Ribić-Zelenović ${ }^{1}$, Pavle Spasojević ${ }^{2}$, Časlav Lačnjevac ${ }^{3}$, Miroslav Spasojević ${ }^{1}$}

${ }^{1}$ Faculty of Agronomy, Čačak, University of Kragujevac, Čačak, Serbia

${ }^{2}$ Faculty of Technical Sciences $\check{C} a c ̌ a k$, University of Kragujevac, Čačak, Serbia

${ }^{3}$ Faculty of Agriculture, University of Belgrade, Zemun, Serbia

Corresponding author: lenka@kg.ac.rs

\begin{abstract}
This research deals with the effect of current density and benzaldehyde and ethanol concentrations on current efficiency for benzaldehyde reduction at the cathodes: a)-Raney-Ni; b)-a titanium substrate having an electrochemically deposited $\mathrm{Ni}_{92} \mathrm{Mo}_{8}$ alloy coating; c)-a titanium substrate having a $\mathrm{Ni}_{93} \mathrm{Mo}_{7}$ alloy coating produced by the plasma spraying process; d)-a cathode made from pressed electrogenerated $\mathrm{Ni}_{92.8} \mathrm{Mo}_{7.2}$ powder and e)-a zinc amalgam cathode $\mathrm{Zn}(\mathrm{Hg})$. Current efficiency increases with benzaldehyde concentration in the solution increasing from $0.4 \mathrm{~mol} \mathrm{dm}^{-3}$ to $1.2 \mathrm{~mol} \mathrm{dm}^{-3}$. The increase in current efficiency is due to the increased rate of the reaction of adsorbed benzol intermediates with water molecules. The increase in current density leads to a decrease in the cathodic current efficiency. The decrease is caused by the small effect of the cathodic overpotential on the rate of the chemical reaction of benzol intermediates with water. As ethanol content in the solution increases, the cathodic current efficiency decreases.
\end{abstract}

Keywords: benzaldehyde, benzyl alcohol, pinacol, electrochemical reduction, $\alpha-$ hydroxybenzyl radical. 


\section{Introduction}

Electrolysis of aldehyde solutions can simultaneously produce corresponding alcohols and acids (Jokic et al., 1991; Ristić et al., 1991; Lačnjevac et al., 2000; Spasojević et al., 2010). Benzyl alcohol and benzoic acid are simultaneously generated by the electrolysis of alkaline solutions of bromides and benzaldehydes (Lačnjevac et al., 2000).

Benzyl alcohol is a precursor to esters, used in the manufacture of perfumes to impart particular odors. Benzoic acid and its salts benzoates are used as antibacterial and antifungal agents in medicine and the food industry, and as preservatives in fruit juices, carbonated beverages and many other foodstuffs. High amounts of benzoic acid are used in the paint and varnish industry as well as in the production of benzoyl peroxide, an initiator for many organic reactions.

Owing to the simultaneous production of benzyl alcohol and benzoic acid, an electrochemical proces scan take place with lower energy consumption than in a conventional chemical process based on heterogeneous catalytic reactions.

The simultaneous generation of benzyl alcohol and benzoic acid from benzaldehyde takes place in an electrochemical cell equipped with an ionselective membrane that separates the anode and cathode compartments (Lačnjevac et al., 2000). Benzaldehyde exhibits relatively low water solubility. This is why the following solvents have been used in research: methanol, ethanol and mixtures of these alcohols and water, acetonitrile, 1-butil-1methylpyrrolidinium triflimide etc. (Saveant and Tessier, 1978; Birkett and Kuhn, 1980; Fawcett and Lasia, 1981; Andrieux et al., 1991a; Andrieux et al., 1991b; Atobe and Nonaka, 1997; Libot and Pletcher, 2000; Doherty and Brooks, 2004; Firoz Babu et al., 2011).

The electrolysis of alkaline solutions containing benzaldehyde and potassium bromide at low overpotentials at DSA anodes results in the evolution of elementary bromide, which in an alkaline environment hydrolyses instantly to hypobromite. The resulting hypobromite oxidizes benzaldehyde to benzoic acid. The anodic current efficiency is about 97\%. Current losses occur through the anodic oxidation of hypobromite to bromate (Jokic et al., 1991; Ristić et al., 1991; Lačnjevac et al., 2000; Spasojević et al., 2010).

Two parallel reactions take place at the cathode: hydrogen evolution and benzaldehyde reduction. The effects of $\mathrm{pH}$, current density, nature of the electrode material and solvent on current efficiency and benzaldehyde reduction mechanism have been reported in a number of articles (Jokic et al., 1991; Ristić et al., 1991; Lačnjevac et al., 2000; Spasojević et al., 2010; Saveant and Tessier, 1978; Birkett and Kuhn, 1980; Fawcett and Lasia, 1981; Andrieux et al.,1991a; Andrieux et al., 1991b; Atobe and Nonaka, 1997; Libot and Pletcher, 2000; Doherty and Brooks, 2004; Firoz Babu et al., 2011). In an alkaline environment, the primary reduction process involves the formation of the radical anion: 


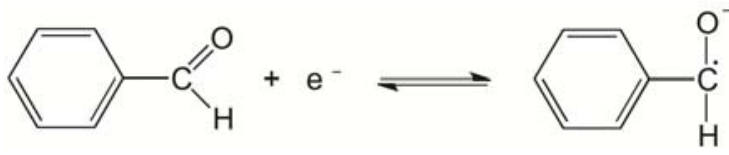

(1)

The ensuing radical anion can be further reduced in one electron process to dianion at more cathodic potentials or can react with water yielding an $\alpha$ hydroxybenzyl radical:

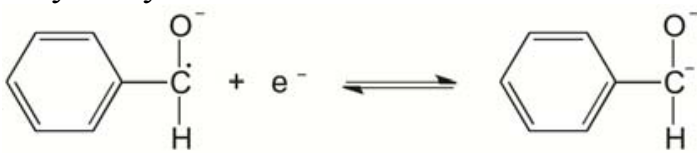

(2)

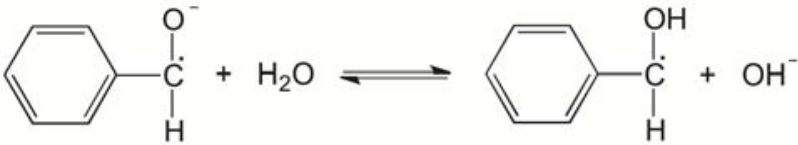

(3)

Unusually, the protonated neutral radical reduces at potentials more cathodic than the parent reduction and occurs at potentials between the initial parent reduction and the radical anion reduction process (Saveant and Tessier, 1978; Birkett and Kuhn, 1980; Andrieux et al. 1991a; Atobe and Nonaka, 1997; Doherty and Brooks, 2004; Firoz Babu et al., 2011):

(4)

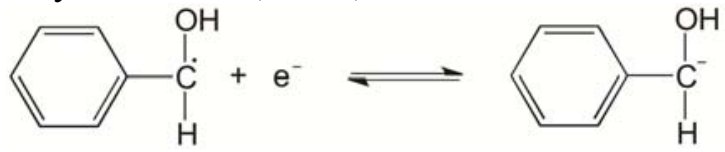

The dianion and the $\alpha$-hydroxybenzyl radical react with water to form alcohol or alcholate:

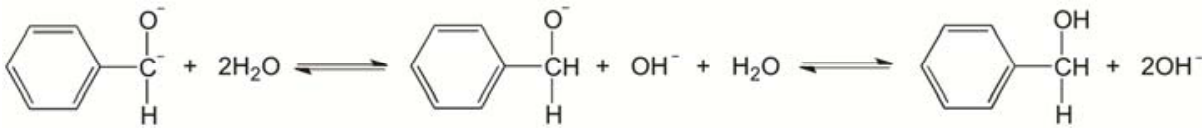

(5)

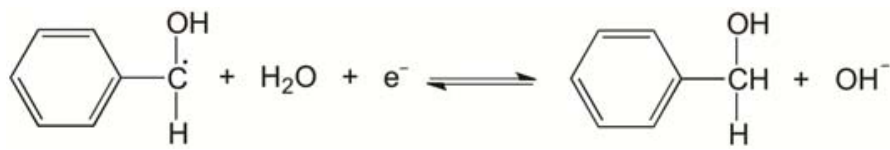

(6)

Dimerisation of the anion radical and that of $\alpha$-hydroxybenzyloccur in parallel (Saveant and Tessier, 1978; Birkett and Kuhn, 1980; Andrieux et al. 1991a; Doherty and Brooks, 2004):<smiles>[O-][C]([O-])c1ccccc1C([O-])C([O-])c1ccccc1</smiles> 


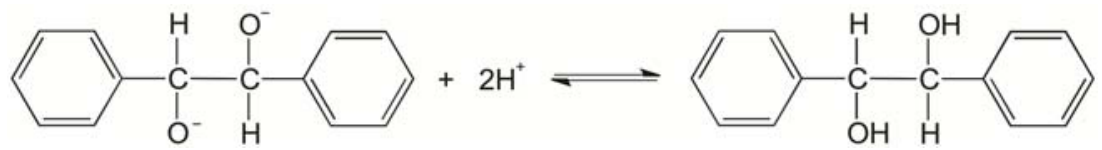

(8)

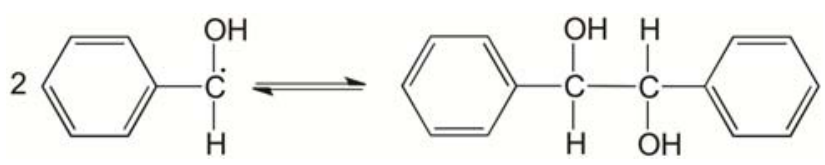

(9)

Benzaldehyde reductionat more positive potentials and polymerization generate diol (pinacol) (Equations 8 and 9) or stabilized dialcoholate species (Equation 7). At more cathodic potentials, benzyl alcohol and alcoholate are produced (Equations 5 and 6) (Saveant and Tessier ,1978; Birkett and Kuhn, 1980; Andrieux et al. 1991a; Doherty and Brooks, 2004).

The objective of this study was to examine the effect of the nature of certain cathodic materials, benzaldehyde concentration and ethanol content in the ethanol-water mixture on current efficiency for the cathodic reduction of benzaldehyde.

\section{Experimental}

The experiment was conducted in a glass electrochemical cell equipped with an ion-selective membrane that separates the cathode and anode compartments (Flemion, Asahi Glass). A $10 \mathrm{~cm}^{2}$ DSA (a titanium substrate having an active coating of $40 \mathrm{~mol} \% \mathrm{RuO}_{2}, 60 \mathrm{~mol} \% \mathrm{TiO}_{2}$ ) was used as the anode. The cathodes included: a) -Raney-Ni; b) - a titanium substrate having an electrochemically deposited $\mathrm{Ni}_{92} \mathrm{Mo}_{8}$ coating; c) - a titanium substrate having a plasma-sprayed $\mathrm{Ni}_{93} \mathrm{Mo}_{7}$ alloy coating; d) - a cathode made from pressed electrogenerated $\mathrm{Ni}_{92.8} \mathrm{Mo}_{7.2}$ powder and e) a zinc amalgam cathode. The working surface area of the cathode was $3 \mathrm{~cm}^{2}$.

The titanium cathode having the electrodeposited $\mathrm{Ni}_{92} \mathrm{Mo}_{8}$ coating and the $\mathrm{Ni}_{92.8} \mathrm{Mo}_{7.2}$ alloy powder for the pressed electrode were obtained in a standard electrochemical cell with a separate compartment for the reference saturated calomel electrode. The anode was a $9 \mathrm{~cm}^{2}$ platinum plate, and the cathodes were titanium plates of $3 \mathrm{~cm}^{2}$ surface area. The $\mathrm{Ni}_{92} \mathrm{Mo}_{8}$ coating was obtained by the electrolysis of the solution composed of $100 \mathrm{~g} \mathrm{dm}^{-3} \mathrm{NiSO}_{4} \cdot 7 \mathrm{H}_{2} \mathrm{O} ; 5 \mathrm{~g} \mathrm{dm}^{-3}$ $\left(\mathrm{NH}_{4}\right)_{6} \mathrm{Mo}_{7} \mathrm{O}_{24} \cdot 4 \mathrm{H}_{2} \mathrm{O} ; 4 \mathrm{~g} \mathrm{dm}^{-3} \mathrm{NaCl}, 200 \mathrm{~cm}^{3} 25 \% \mathrm{NH}_{4} \mathrm{OH}$ at a current density of $15 \mathrm{~mA} \mathrm{~cm}{ }^{-2}$ and $\mathrm{t}=25^{\circ} \mathrm{C}$. The $\mathrm{Ni}_{92.8} \mathrm{Mo}_{7.2}$ alloy powder was produced by the electrolysis of the solution $100 \mathrm{~g} \mathrm{dm}^{-3} \quad \mathrm{NiSO}_{4} \cdot 7 \quad \mathrm{H}_{2} \mathrm{O} ; 13 \quad \mathrm{~g} \mathrm{dm}^{-3}$ $\left(\mathrm{NH}_{4}\right)_{6} \mathrm{Mo}_{7} \mathrm{O}_{24} \cdot 4 \mathrm{H}_{2} \mathrm{O} ; 4 \mathrm{~g} \mathrm{dm}^{-3} \mathrm{NaCl}, 200 \mathrm{~cm}^{3} 25 \% \mathrm{NH}_{4} \mathrm{OH}$ at a current density of $100 \mathrm{mAcm}^{-2}$ and $\mathrm{t}=25^{\circ} \mathrm{C}$. Pressing the powder at a pressure of $5000 \mathrm{MPa}$ at $25^{\circ} \mathrm{C}$ produced a $3 \mathrm{~mm}$ thick plate-shaped electrode. A zinc amalgam electrode $\mathrm{Zn}(\mathrm{Hg})$ 
was obtained by the electrochemical deposition of zinc from a sulfate bath composed of $35 \mathrm{~g} \mathrm{dm}^{-3} \mathrm{ZnSO}_{4} ; 30 \mathrm{~g} \mathrm{dm}^{-3}\left(\mathrm{NH}_{4}\right)_{2} \mathrm{SO}_{4}$ at $\mathrm{t}=25^{\circ} \mathrm{C}$. First, at a low current density $\left(5 \mathrm{~mA} \mathrm{~cm}^{-2}\right)$, a compact shiny adherent zinc coating was formed on the titanium plate. Then, a rough layer of large real surface area was deposited onto this layer at a current density of $20 \mathrm{~mA} \mathrm{~cm}$. The resulting electrochemically obtained coating was dipped for $60 \mathrm{~s}$ at $20^{\circ} \mathrm{C}$ into a $0.1 \mathrm{~mol}$ $\mathrm{dm}^{-3} \mathrm{HgCl}_{2}$ solution.

A mixture of ethanol and water was used as the solvent for the electrochemical investigation of benzaldehyde reduction. The solution contained $0.8 \mathrm{~mol} \mathrm{dm}^{-3} \mathrm{KOH}, 0.8 \mathrm{~mol} \mathrm{dm}^{-3} \mathrm{KBr}$ and benzaldehyde $\left(\mathrm{C}_{6} \mathrm{H}_{5}-\mathrm{CHO}\right)$. Benzaldehyde concentration ranged from $0.4 \mathrm{~mol} \mathrm{dm}^{-3}$ to $1.2 \mathrm{~mol} \mathrm{dm}^{-3}$. The solutions were prepared using triple distilled water and p.a. chemicals. The standard circuitry included a programmer, a PAR-273 potentiostat and a digital voltmeter, Pro's Kit 03-9303c. The cathodic current efficiency for benzaldehyde reduction was determined by measuring the contents of benzaldehyde and pinacolon a HPLC, Waters, and by measuring the rate of hydrogen evolution and the time required for the cathodically evolved hydrogen to fill up a volumetric burette placed above the cathode.

\section{Results and discussion}

The current efficiency for benzaldehyde reduction is dependent on the nature of the cathode material, current density, benzaldehyde concentration and solvent composition.

Figure 1.presents current efficiency as affected bycathodic current density and benzaldehyde concentration when a pressed $\mathrm{Ni}_{92.8} \mathrm{Mo}_{7.2}$ cathode is used. The diagram shows that current efficiency decreases abruptly with increasing current density at low-range densities, $\mathrm{j}<45 \mathrm{~mA} \mathrm{~cm}^{-2}$. At higher current densities, the decrease occurs at a slower rate. Adsorbed intermediates exist on the cathode surface, with their degree of adsorption depending on the nature of the electrode material, potential, and benzaldehyde and ethanol concentrations in the solution. In the benzaldehyde reduction mechanism, the reactions of intermediates with water (reactions (3) and (5)) most likely represent the rate determining step. The increase in the cathodic overpotential changes the value of saturation coverage of the electrodes by intermediates, thus indirectly causing relatively small changes in the rate of reactions (3) and (5). However, the increasing overpotential leads to a substantial increase in the rate of hydrogen evolution, resulting in decreased current efficiency. With increasing benzaldehyde concentration in the solution, current efficiency increases at all current densities. Increased benzaldehyde concentration in the solution causes larger coverage of the cathode by intermediates and, hence, a higher rate of reactions (3) and (5). 


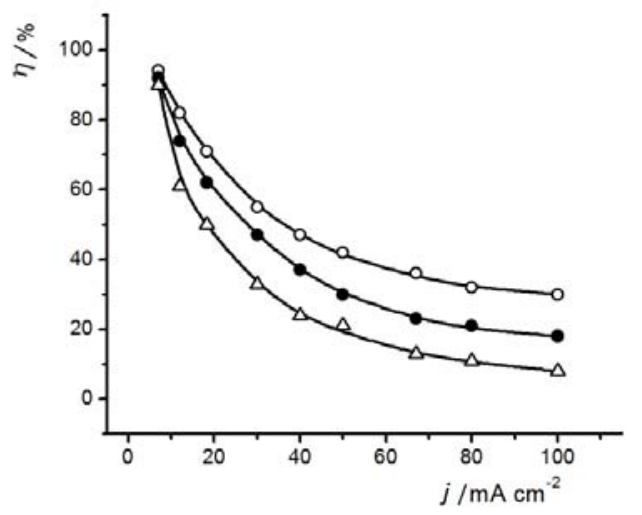

Figure 1. Current efficiency, $\eta$, for benzaldehyde reduction as a function of current density, $\mathrm{j}$, and benzaldehyde concentration: $0-1.2 \mathrm{~mol} \mathrm{dm}^{-3} \mathrm{C}_{6} \mathrm{H}_{5}-\mathrm{CHO}$;

- $0.8 \mathrm{~mol} \mathrm{dm}^{-3} \mathrm{C}_{6} \mathrm{H}_{5}-\mathrm{CHO} ; \Delta-0.4 \mathrm{~mol} \mathrm{dm}{ }^{-3} \mathrm{C}_{6} \mathrm{H}_{5}-\mathrm{CHO}$, at pressed $\mathrm{Ni}_{92.8} \mathrm{Mo}_{7.2}$ cathode (90 wt. $\% \mathrm{C}_{2} \mathrm{H}_{5} \mathrm{OH}, 10$ wt. $\% \mathrm{H}_{2} \mathrm{O} ; 0.8 \mathrm{~mol} \mathrm{dm}^{-3} \mathrm{KOH} ; 0.8 \mathrm{~mol} \mathrm{dm}{ }^{-3} \mathrm{KBr}$; $\left.\mathrm{t}=25^{\circ} \mathrm{C}\right)$.

Figures 2. and 3. present the dependence of the current efficency for benzaldehyde reduction on current density and benzaldehyde concentration when using titanium cathodes activated: by an electrochemically deposited coating of $\mathrm{Ni}_{92} \mathrm{Mo}_{8}$ alloy (Fig. 2) and by a plasma-sprayed $\mathrm{Ni}_{93} \mathrm{Mo}_{7}$ coating (Fig. 3).

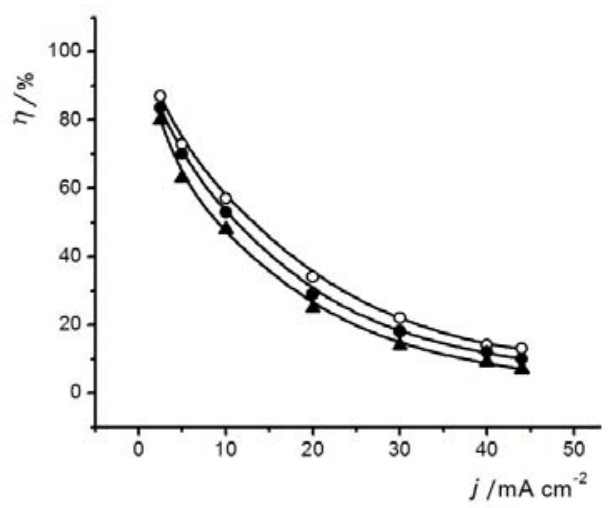

Figure 2. Current efficiency, $\eta$, for benzaldehyde reduction as a function of current density, $\mathrm{j}$, and benzaldehyde concentration: $\bigcirc-1.2 \mathrm{~mol} \mathrm{dm}^{-3} \mathrm{C}_{6} \mathrm{H}_{5}-\mathrm{CHO}$; - $0.8 \mathrm{~mol} \mathrm{dm}^{-3} \mathrm{C}_{6} \mathrm{H}_{5}-\mathrm{CHO} ; \boldsymbol{\Delta}-0.4 \mathrm{~mol} \mathrm{dm}{ }^{-3} \mathrm{C}_{6} \mathrm{H}_{5}-\mathrm{CHO}$, on an electrochemically produced $\mathrm{Ni}_{92} \mathrm{Mo}_{8}$ coating $\left(90\right.$ wt. $\% \mathrm{C}_{2} \mathrm{H}_{5} \mathrm{OH}, 10$ wt. $\% \mathrm{H}_{2} \mathrm{O}$; $0.8 \mathrm{~mol} \mathrm{dm}^{-3} \mathrm{KOH} ; 0.8 \mathrm{~mol} \mathrm{dm}^{-3} \mathrm{KBr}$; $\mathrm{t}=25^{\circ} \mathrm{C}$ ). 


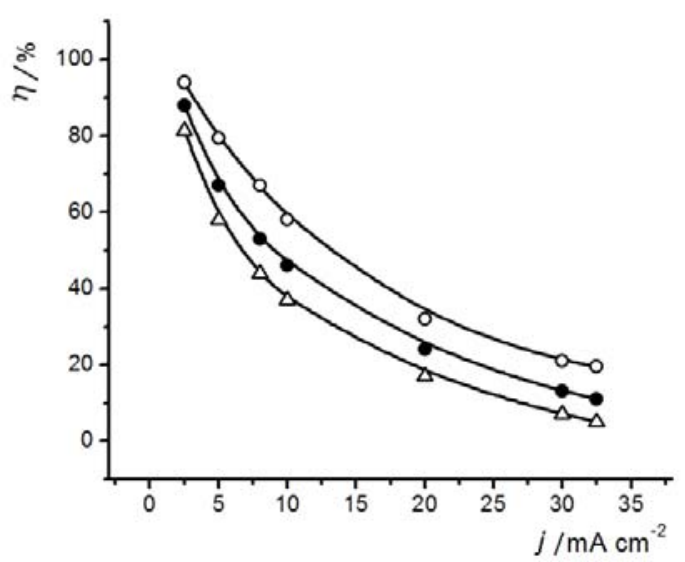

Figure 3. Current efficiency, $\eta$, for benzaldehyde reduction as a function of current density, $\mathrm{j}$, and benzaldehyde concentration: $\mathrm{O}-1.2 \mathrm{~mol} \mathrm{dm}^{-3} \mathrm{C}_{6} \mathrm{H}_{5}-\mathrm{CHO}$; - $0.8 \mathrm{~mol} \mathrm{dm}{ }^{-3} \mathrm{C}_{6} \mathrm{H}_{5}-\mathrm{CHO} ; \Delta-0.4 \mathrm{~mol} \mathrm{dm}{ }^{-3} \mathrm{C}_{6} \mathrm{H}_{5}-\mathrm{CHO}$, on a $\mathrm{Ni}_{93} \mathrm{Mo}_{7}$ coating formed by the plasma process $\left(90\right.$ wt. $\% \mathrm{C}_{2} \mathrm{H}_{5} \mathrm{OH} ; 10 \mathrm{wt} . \% \mathrm{H}_{2} \mathrm{O} ; 0.8 \mathrm{~mol} \mathrm{dm}^{-3}$ $\left.\mathrm{KOH} ; 0.8 \mathrm{~mol} \mathrm{dm}^{-3} \mathrm{KBr} ; \mathrm{t}=25^{\circ} \mathrm{C}\right)$.

The diagrams in Figures 2 and 3 show that a similar dependence of current efficiency on current density and benzaldehyde concentration exists on the coatings formed by electrochemical and plasma processesandon the pressed cathode. The difference is only in that current efficiency decreases more rapidly with increasing current density on these coatings than on the pressed cathode. This is due to: a) considerably larger real surface area of the pressed cathode, and b) - its microstructure. The pressed electrode material consists of nanocrystals of the FCC-structured solid solution of molybdenum in nickel which exhibita high internal microstrain and a high number of chaotically distributed dislocations (Ribić-Zelenović et al., 2007; Ribić-Zelenović et al., 2008; Ribić-Zelenović et al., 2009; Spasojević et al., 2009). The specific nanostructure of the cathode catalyst probably has adequate active centres on its surface where reactions (3) and (5) take place at a faster rate than on the electrodes formed by electrochemical and plasma processes.

The highest current efficiencies are obtained when using $\mathrm{Zn}(\mathrm{Hg})$ electrodes (Fig. 4).

The comparison of the diagrams in Figures 1. and 4. suggests that the decrease in benzaldehyde concentration in the solution causes a higher decrease in current efficiency on the pressed $\mathrm{Ni}_{92.8} \mathrm{Mo}_{7.2}$ cathode than on $\mathrm{Zn}(\mathrm{Hg})$ cathode. The $\mathrm{Zn}(\mathrm{Hg})$ cathode operating at about $0.65 \mathrm{~V}$ more negative potential than the pressed $\mathrm{Ni}_{92.8} \mathrm{Mo}_{7.2}$ cathode exhibits a considerably lower decrease in equilibrium coverage by intermediates with benzaldehyde concentration in the 
solutiondecreasing from $1.2 \mathrm{~mol} \mathrm{dm}^{-3}$ to $0.4 \mathrm{~mol} \mathrm{dm}^{-3}$. This causes a higher decrease in the rate of reactions (3) and (5) and, hence, a higher decline in current efficiency at the pressed $\mathrm{Ni}_{92.8} \mathrm{Mo}_{7.2}$ cathode.

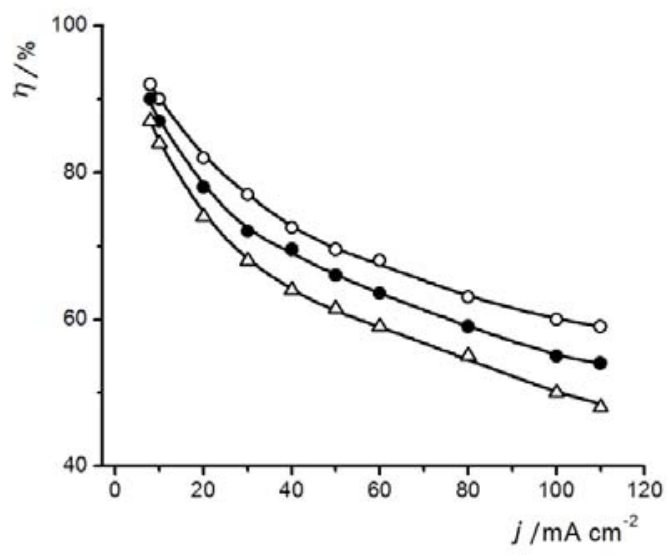

Figure 4. Current efficiency, $\eta$, for benzaldehyde reduction as a function of current density, $\mathrm{j}$, and benzaldehyde concentration: $\circ-1.2 \mathrm{~mol} \mathrm{dm}^{-3} \mathrm{C}_{6} \mathrm{H}_{5}-\mathrm{CHO}$; - $-0.8 \mathrm{~mol} \mathrm{dm}^{-3} \mathrm{C}_{6} \mathrm{H}_{5}-\mathrm{CHO} ; \Delta-0.4 \mathrm{~mol} \mathrm{dm}^{-3} \mathrm{C}_{6} \mathrm{H}_{5}-\mathrm{CHO}$, at the $\mathrm{Zn}(\mathrm{Hg})$ cathode (90 wt. $\% \mathrm{C}_{2} \mathrm{H}_{5} \mathrm{OH}, 10$ wt. $\% \mathrm{H}_{2} \mathrm{O} ; 0.8 \mathrm{~mol} \mathrm{dm}^{-3} \mathrm{KOH} ; 0.8 \mathrm{~mol} \mathrm{dm}^{-3} \mathrm{KBr}$; $\left.\mathrm{t}=25^{\circ} \mathrm{C}\right)$.

Figures 5. and 6. show the effect of the nature of the cathode material, current density and solvent composition on current efficiency.

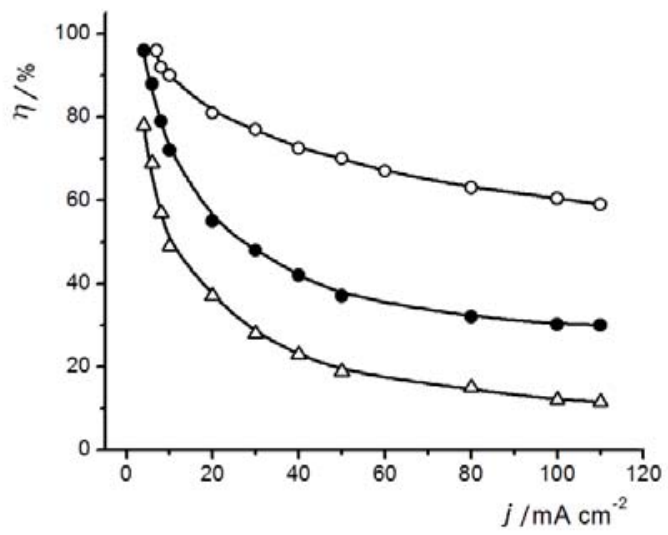

Figure 5. Current efficiency, $\eta$, as a function of current density, $\mathrm{j}$, and nature of the cathode material: ० - $\mathrm{Zn}(\mathrm{Hg}) ; \bullet$ - pressed $\mathrm{Ni}_{92.8} \mathrm{Mo}_{7.2} ; \Delta$ - Raney - $\mathrm{Ni}(90$ wt. $\% \mathrm{C}_{2} \mathrm{H}_{5} \mathrm{OH}, 10$ wt. $\% \mathrm{H}_{2} \mathrm{O} ; 0.8 \mathrm{~mol} \mathrm{dm}{ }^{-3} \mathrm{KOH} ; 0.8 \mathrm{~mol} \mathrm{dm}{ }^{-3} \mathrm{KBr} ; 1.2 \mathrm{~mol} \mathrm{dm}-$ ${ }^{3} \mathrm{C}_{6} \mathrm{H}_{5}-\mathrm{CHO} ; \mathrm{t}=25^{\circ} \mathrm{C}$ ). 


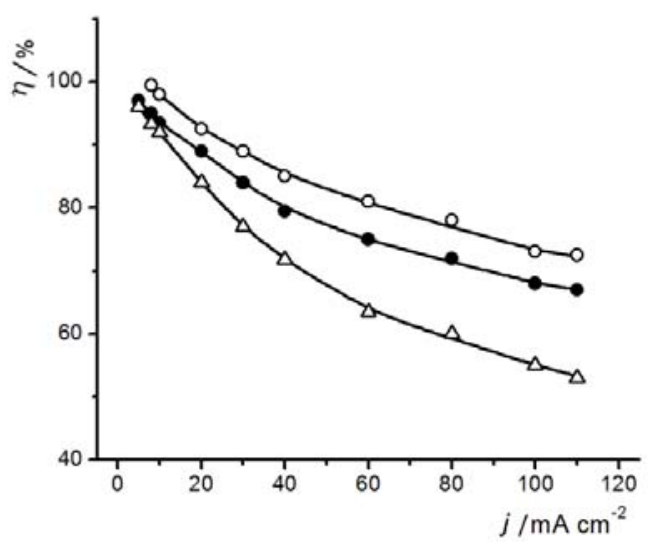

Figure 6. Current efficiency, $\eta$, as a function of current density, $\mathrm{j}$, and nature of the cathode material: $\bigcirc-\mathrm{Zn}(\mathrm{Hg}) ; \bullet-$ pressed $\mathrm{Ni}_{92.8} \mathrm{Mo}_{7.2} ; \Delta$ - Raney - Ni (30 wt. $\% \mathrm{C}_{2} \mathrm{H}_{5} \mathrm{OH} ; 70$ wt. $\% \mathrm{H}_{2} \mathrm{O} ; 0.8 \mathrm{~mol} \mathrm{dm}{ }^{-3} \mathrm{KOH} ; 0.8 \mathrm{~mol} \mathrm{dm}{ }^{-3} \mathrm{KBr} ; 1.2 \mathrm{~mol} \mathrm{dm}^{-}$ $\left.{ }^{3} \mathrm{C}_{6} \mathrm{H}_{5}-\mathrm{CHO} ; \mathrm{t}=25^{\circ} \mathrm{C}\right)$.

The diagrams show that the highest current efficiencies are obtained when amalgam $\mathrm{Zn}(\mathrm{Hg})$ and pressed $\mathrm{Ni}_{92.8} \mathrm{Mo}_{7.2}$ cathodes are used. The electrolysis of the solution 30 wt. $\% \mathrm{C}_{2} \mathrm{H}_{5} \mathrm{OH} ; 70$ wt. $\% \mathrm{H}_{2} \mathrm{O} ; 0.8 \mathrm{~mol} \mathrm{dm}{ }^{-3} \mathrm{KOH} ; 0.8 \mathrm{~mol} \mathrm{dm}^{-3}$ $\mathrm{KBr} ; 1.2 \mathrm{~mol} \mathrm{dm}{ }^{-3} \mathrm{C}_{6} \mathrm{H}_{5}-\mathrm{CHO}$ at $\mathrm{t}=25^{\circ} \mathrm{C}$ at the pressed $\mathrm{Ni}_{92.8} \mathrm{Mo}_{7.2}$ cathode produces current efficiencies that are only 5\% lower than at the amalgam $\mathrm{Zn}(\mathrm{Hg})$ cathode. The diagrams in Figures 5. and 6. also suggest a high effect of current efficiency on ethanol content in the solution. This effect of ethanol content on current efficiency at pressed $\mathrm{Ni}_{92.8} \mathrm{Mo}_{7.2}, \mathrm{Zn}(\mathrm{Hg})$ and Raney-Ni cathodes is presented in Figures 7, 8. and 9. 


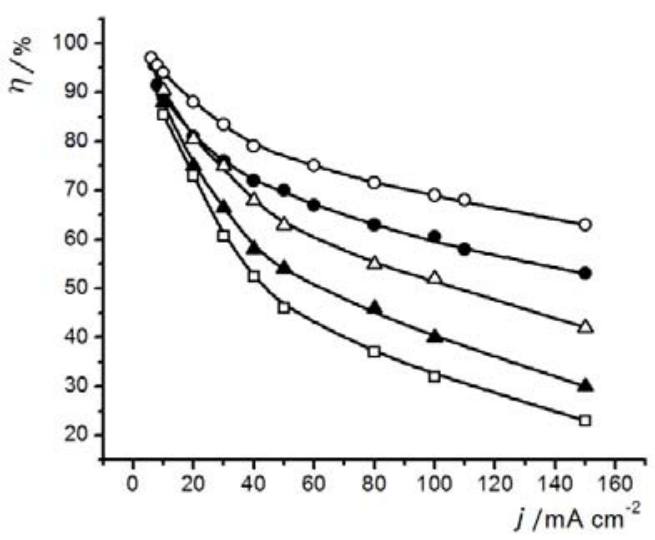

Figure 7. Current efficiency, $\eta$, as a function of current density, $\mathrm{j}$, and solvent composition: ○ -30 wt. $\% \mathrm{C}_{2} \mathrm{H}_{5} \mathrm{OH}, 70$ wt. $\% \mathrm{H}_{2} \mathrm{O} ; \bullet-40$ wt. $\% \mathrm{C}_{2} \mathrm{H}_{5} \mathrm{OH} ; 60$ wt. $\%$ $\mathrm{H}_{2} \mathrm{O} ; \Delta$ - 50 wt. $\% \mathrm{C}_{2} \mathrm{H}_{5} \mathrm{OH} ; 50$ wt. $\% \mathrm{H}_{2} \mathrm{O} ; \boldsymbol{\Delta}$ - 70 wt. $\% \mathrm{C}_{2} \mathrm{H}_{5} \mathrm{OH} ; 30$ wt. $\% \mathrm{H}_{2} \mathrm{O} ; \square$

- 90 wt. $\% \mathrm{C}_{2} \mathrm{H}_{5} \mathrm{OH} ; 10$ wt. $\% \mathrm{H}_{2} \mathrm{O}$; at the pressed $\mathrm{Ni}_{92.8} \mathrm{Mo}_{7.2}$ cathode $(0.8$ mol $\mathrm{dm}^{-3} \mathrm{KOH}$; $0.8 \mathrm{~mol} \mathrm{dm} \mathrm{KBr}^{-3} 1.2 \mathrm{~mol} \mathrm{dm}^{-3} \mathrm{C}_{6} \mathrm{H}_{5}-\mathrm{CHO}$; $\left.\mathrm{t}=25^{\circ} \mathrm{C}\right)$.

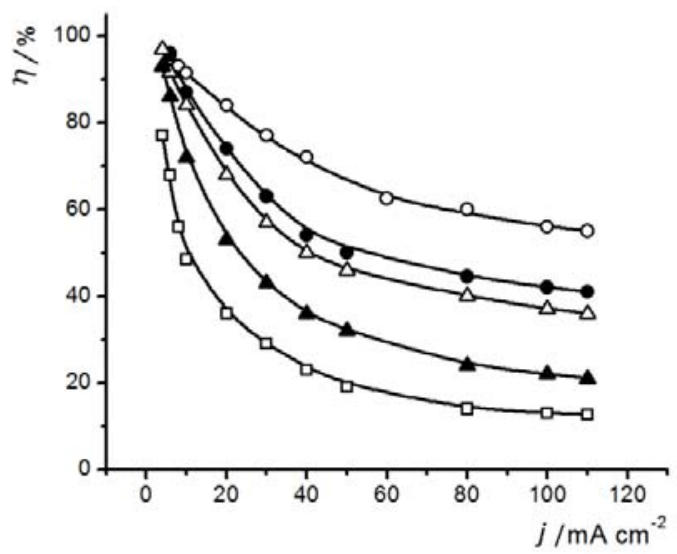

Figure 8. Current efficiency, $\eta$, as a function of current density, $\mathrm{j}$, and solvent compostion: ○ - 30 wt. $\% \mathrm{C}_{2} \mathrm{H}_{5} \mathrm{OH} ; 70$ wt. $\% \mathrm{H}_{2} \mathrm{O} ; \bullet-40$ wt. $\% \mathrm{C}_{2} \mathrm{H}_{5} \mathrm{OH} ; 60$ wt.\% $\mathrm{H}_{2} \mathrm{O} ; \Delta$ - 50 wt. $\% \mathrm{C}_{2} \mathrm{H}_{5} \mathrm{OH} ; 50$ wt. $\% \mathrm{H}_{2} \mathrm{O} ; \boldsymbol{\Delta}$ - 70 wt. $\% \mathrm{C}_{2} \mathrm{H}_{5} \mathrm{OH} ; 30$ wt. $\% \mathrm{H}_{2} \mathrm{O}$; 口 - 90 wt. $\% \mathrm{C}_{2} \mathrm{H}_{5} \mathrm{OH} ; 10$ wt. $\% \mathrm{H}_{2} \mathrm{O}$; at Riney-Ni cathode $\left(0.8 \mathrm{~mol} \mathrm{dm}{ }^{-3} \mathrm{KOH}\right.$; $0.8 \mathrm{~mol} \mathrm{dm}^{-3} \mathrm{KBr} ; 1.2 \mathrm{~mol} \mathrm{dm}^{-3} \mathrm{C}_{6} \mathrm{H}_{5}-\mathrm{CHO}$; $\left.\mathrm{t}=25^{\circ} \mathrm{C}\right)$. 


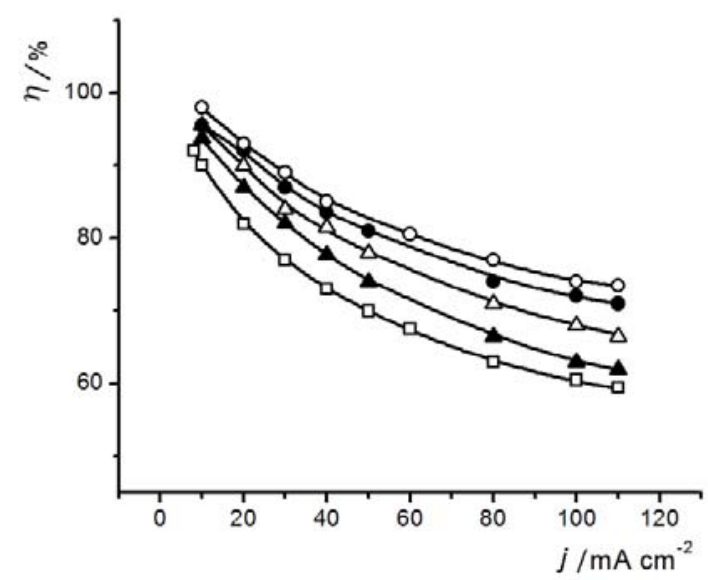

Figure 9. Current efficiency, $\eta$, as a function of current density, $\mathrm{j}$, and solvent compostion: ○ - 30 wt. $\% \mathrm{C}_{2} \mathrm{H}_{5} \mathrm{OH} ; 70$ wt. $\% \mathrm{H}_{2} \mathrm{O} ; \bullet-40$ wt. $\% \mathrm{C}_{2} \mathrm{H}_{5} \mathrm{OH} ; 60$ wt. $\%$ $\mathrm{H}_{2} \mathrm{O} ; \Delta$ - 50 wt. $\% \mathrm{C}_{2} \mathrm{H}_{5} \mathrm{OH} ; 50$ wt. $\% \mathrm{H}_{2} \mathrm{O} ; \boldsymbol{\Delta}$ - 70 wt. $\% \mathrm{C}_{2} \mathrm{H}_{5} \mathrm{OH} ; 30$ wt. $\% \mathrm{H}_{2} \mathrm{O}$; 口 - 90 wt. $\% \mathrm{C}_{2} \mathrm{H}_{5} \mathrm{OH} ; 10$ wt. $\% \mathrm{H}_{2} \mathrm{O}$ at $\mathrm{Zn}(\mathrm{Hg})$ cathode $\left(0.8 \mathrm{~mol} \mathrm{dm}{ }^{-3} \mathrm{KOH} ; 0.8\right.$ mol dm${ }^{-3} \mathrm{KBr} ; 1.2 \mathrm{~mol} \mathrm{dm}^{-3} \mathrm{C}_{6} \mathrm{H}_{5}-\mathrm{CHO}$; $\left.\mathrm{t}=25^{\circ} \mathrm{C}\right)$.

The diagrams in Figs. 7, 8. and 9 show that current efficiency at all cathodes decreases with increasing ethanol content in the solution. On the cathode surface, there is simultaneous absorption of: a) benzaldehyde and its intermediates (radical anion, dianion, $\alpha$-hydroxybenzyl radical), b) hydrogen and c) ethanol. The increase in ethanol concentration in the solution increases the adsorption of ethanol while decreasing the adsorption of all other particles. This causes a reduction in both hydrogen evolution rate and benzaldehyde reduction rate. The adsorption of ethanol has a more suppressive effect on the adsorption of benzaldehyde intermediates than on hydrogen adsorption since it takes one free adsorption site for the adsorption of one hydrogen atom, and more neighbouring free adsorption sites for the adsorption of benzol and its intermediates. The increase in the degree of cathode coverage by adsorbed ethanol results in a faster decrease in the number of sets of several neighbouring fee surface atoms than in the number of free atoms (Adžić et al., 1979a; Adžić et al., 1979b). The faster decrease in the number of these sets leads to a higher decrease in the rate of reactions (3) and (5) than in the rate of hydrogen evolution reaction, thus leading to a decrease in current efficiency.

The composition of benzaldehyde reduction products depends on current density. At low current densities $\left(\mathrm{j}<30 \mathrm{~mA} \mathrm{~cm}{ }^{-3}\right)$, pinacol is the major product, whereas benzyl alcohol dominates at high current densities. Thus, at $\mathrm{j}=100 \mathrm{~mA}$ $\mathrm{cm}^{-2}, 94 \mathrm{wt} . \%$ benzaldehyde and 6 wt.\% pinacol are produced at the $\mathrm{Zn}(\mathrm{Hg})$ 
cathode, and 92 wt.\% benzyl alcohol and 8 wt.\% pinacol at the pressed $\mathrm{Ni}_{92.8} \mathrm{Mo}_{7.2}$ cathode.

The results show that $\mathrm{Zn}(\mathrm{Hg})$ and pressed $\mathrm{Ni}_{92.8} \mathrm{Mo}_{7.2}$ cathodes can be used in industrial electrochemical cells for the production of benzyl alcohol with a high current efficiency obtained. In the electrolysis of concentrated benzaldehyde solutions using pressed $\mathrm{Ni}_{92.8} \mathrm{Mo}_{7.2}$ cathodes, the current efficiency is several percentage points lower at a current density of $100 \mathrm{~mA} \mathrm{~cm}^{-2}$ and at a potential that is $0.64 \mathrm{~V}$ more positive than that of the $\mathrm{Zn}(\mathrm{Hg})$ cathode.

The electrochemical production of benzyl acohol in adequately designed plants employing these electrodes can have lower energy consumption compared to plants where benzyl alcohol is obtained by conventional chemical heterogeneous catalytic hydrogenation. The energy efficiency of the electrochemical process is also substantially increased by the simultaneous production of benzoic acid through benzaldehyde oxidation.

\section{Conclusion}

The cathodic current efficiency of benzaldehyde reduction was found to depend on current density and benzaldehyde and ethanol contents in solution at the cathodes: a) - Raney - Ni; b) a titanium substrate having an electrochemically deposited $\mathrm{Ni}_{92} \mathrm{Mo}_{8}$ alloy coating; c) - a titanium substrate having a $\mathrm{Ni}_{93} \mathrm{Mo}_{7}$ alloy coating produced by the plasma spraying process; d) - a cathode made from pressed electrogenerated $\mathrm{Ni}_{92.8} \mathrm{Mo}_{7.2}$ powder and e) - a zinc amalgam cathode $\mathrm{Zn}(\mathrm{Hg})$. A current efficiency of about $70 \%$ is obtained in the electrolysis of concentrated benzaldehyde solution $\left(1.2 \mathrm{~mol} \mathrm{dm}^{-3} \mathrm{C}_{6} \mathrm{H}_{5}-\mathrm{CHO}\right)$ containing $30 \mathrm{wt} . \% \mathrm{C}_{2} \mathrm{H}_{5} \mathrm{OH}$, at a current density of $100 \mathrm{~mA} \mathrm{~cm}^{-2}$, at the zinc amalgam and pressed $\mathrm{Ni}_{92.8} \mathrm{Mo}_{7.2}$ cathodes.

Current efficiency decreases with decreasing benzaldehyde concentration in the solution. Low benzaldehyde concentrations lead to low equilibrium coverage of the cathode by intermediates and, hence, a low rate of the slowest step in the benzaldehyde reduction mechanism i.e. the reaction between intermediates and water. As current density increases, current efficiency decreases. The increase in the cathodic overpotential has a much lower effect on the rate of the reaction of intermediates with water than on the hydrogen evolution reaction. The increasing overpotential only indirectly affects the rate of benzaldehyde reduction through the change in the value of equilibrium coverage of the cathode by intermediates. With increasing ethanol content in the solution, the cathodic current efficiency decreases. The decrease is due to the adsorption of ethanol molecules. The adsorbed molecules of ethanol have a more suppressive effect on the adsorption of benzol intermediates than on hydrogen adsorption. It takes one free adsorption site for hydrogen to be adsorbed, whereas an intermediate is adsorbed if a set of several free adsorption sites exists on the surface. The major products of 
benzaldehyde reduction at high and low current densities are benzyl alcohol and pinacol, respectively.

\section{Acknowledgements}

The authors acknowledge financial support from the Ministry of Education and Science of the Republic of Serbia through Project Ref. No. 172057.

\section{References}

Adžić R., Spasojević M., Despić A. (1979): Hydrogen evolution on platinum in the presence of lead, cadmium and thallium adatoms. Electrochimica Acta, 24: 569-576.

Adžić R., Spasojević M., Despić A. (1979): Hydrogen evolution on gold electrode in the presence of lead adatoms. Electrochimica Acta, 24: 577-579.

Andrieux P., Grzeszczuk M., Saveant M. (1991): Electrochemical generation and reduction of organic free radicals. .alpha.-Hydroxybenzyl radicals from the reduction of benzaldehyde. Journal of the American Chemical Society, 113: 88118817.

Andrieux P., Grzeszczuk M., Savéant M. (1991): Electrochemical generation and detection of transient intermediates: Dimerizing species. Journal of Electroanalytical Chemistry and Interfacial Electrochemistry, 318: 369-372.

A tobe M., Nonaka T. (1997): Ultrasonic effects on electro-organic processes Part 7. Reduction of benzaldehydes on ultrasound vibrating electrodes. Journal of Electroanalytical Chemistry, 425: 161-166.

Birkett D., Kuhn T. (1980): The electrochemical reduction of Benzaldehyde. Electrochimica Acta, 25: 273-278.

Doherty P., Brooks A. (2004): Electrosynthesis in room-temperature ionic liquids: benzaldehyde reduction. Electrochimica Acta, 49: 3821-3826.

Fawcett R., Lasia A. (1981): The electroreduction of aromatic aldehydes in aprotic solvents. Canadian Journal of Chemistry, 59: 3256-3260.

Firoz Babu K., Marxe K., Anbu Kulandainathan M. (2011): Anodically fabricated $\mathrm{TiO} 2$ nanopores for electrocatalytic reduction of aldehydes. Journal of Electroanalytical Chemistry, 663: 79-83.

Jokic A., Ristic N., Jaksic M., Spasojevic M., Krstajic N. (1991): Simultaneous electrolytic production of xylitol and xylonic acid from xylose. Journal of Applied Electrochemistry, 21: 321-326.

Lačnjevac Č., Rafailović L., Rotorčević M., Jokić A., Spas ojević M. (2000): Electrolysis of benzaldehyde. 2nd International Conference of the Chemical Societies of the South-Eastern European Countries on Chemical Sciences for Sustainable Development, University of Thessaloniki Library, Halkidiki, 179-184.

Libot C., Pletcher D. (2000): The reduction of carbonyl compounds at carbon electrodes in acidic water/methanol mixtures. Electrochemistry Communications, 2: 141144.

Ribić-Zelenović L., Spasojević M., Maričić A. (2009): The effect of cathodic current density on the microstructure of electrochemically produced 
nanostructured powders of NixMo1-x alloys. Materials Chemistry and Physics, 115: 347351.

Ribić-Zelenović L., Simeunović R., Maričić A., Spasojević M. (2007): The Effect of Temperature on the Magnetic Properties of the Electrochemically Obtained $\mathrm{Ni}_{92.8} \mathrm{Mo}_{7.2}$ Powder Pressed at Different Pressures. Research Trends in Contemporary Materials Science, 555: 539-543.

Ribić-Zelenović L., Spasojević M., Maričić A., Ristić M. (2008): Characteristics of electrochemically obtained Ni96.7Mo3.3 alloy powder. Journal of Optoelectronics and Advanced Materials, 10: 1384-1389.

Ristić N., Jokić A., Spasojević M., Krstajić N., Jakšić M. (1991): Simultaneous electrolytic production of sorbitol and glyconic acid from glucose. Bulletin of Electrochemistry, 7: 461-465.

Saveant M., Tessier D. (1998): Non-Volmerian charge transfers associated with follow-up chemical reactions. A convolution potential sweep voltammetric study of benzaldehyde reduction in ethanol. The Journal of Physical Chemistry, 82: 1723-1727.

Spasojević M., Ribić-Zelenović L., Maričić A., Ristic M. (2009): The effect of structural changes during sintering on the electric and magnetic traits of the Ni96.7Mo3.3 alloy nanostructured powder. Science of Sintering, 41: 175184.

Spasojević M., Ribić-Zelenović L., Trišović T., Đukić D. (2010): A novel catalyst for the electrochemical reduction of d-xylose to xylitole. Twelfth Annual Conference "Yucomat 2010", University of Kotor Library, Herceg Novi, 104. 


\section{UTICAJ GUSTINE STRUJE I SASTAVA RASTVORA NA ISKORIŠĆENJE STRUJE ELEKTROHEMIJSKE REDUKCIJE BENZALDEHIDA}

\section{Lenka Ribić-Zelenović ${ }^{1 *}$, Pavle Spasojević2 ${ }^{2}$ Časlav Lačnjevac ${ }^{3}$, Miroslav Spasojević ${ }^{1}$}

${ }^{1}$ Agronomski Fakultet u Čačku, Univerzitetu Kragujevcu, Čačak, Srbija

${ }^{2}$ Fakultet tehničkih nauka u Čačku, Univerzitetu Kragujevcu, Čačak, Srbija

${ }^{3}$ Agronomski fakultet, UniverzitetuBeogradu, Zemun, Srbija

\section{Izvod}

Ispitivan je uticaj gustine struje, koncentracije benzaldehida i etanola na iskorišćenje struje redukcije benzaldehida na katodama: a) -Raney-Ni; b) titanska osnova sa elektrohemijski deponovanom prevlakom od legure $\mathrm{Ni}_{92} \mathrm{Mo}_{8}$; c) - titanska osnova sa prevlakom od legure $\mathrm{Ni}_{93} \mathrm{Mo}_{7}$ nanetom postupkom plazma prskanja; d) -katoda od presovanog elektrodeponovanog praha $\mathrm{Ni}_{92.8} \mathrm{Mo}_{7.2}$ i e) cink amalgam katoda $\mathrm{Zn}(\mathrm{Hg})$. Iskorišćenje struje raste sa povećanjem koncentracije benzaldehida u rastvoru od $0.4 \mathrm{~mol} \mathrm{dm}^{-3}$ do $1.2 \mathrm{~mol} \mathrm{dm}^{-3}$. Povećanje iskorišćenja struje je rezultat povećanja brzine reakcije adsorbovanih benzolovih intermedijera sa molekulima vode. Povećanje gustine struje dovodi do smanjenja iskorišćenja katodne struje. Pad je uzrokovan manjim uticajem katodne prenapetosti na brzinu hemijske reakcije benzolovih intermedijara sa vodom. Povećanje koncentracije etanola u rastvoru vodi smanjenju iskorišćenja katodne struje.

Ključne reči: benzaldehid, benzil alkohol, pinakol, elektrohemijska redukcija, $\alpha$ hidroksibenzil radikal. 